\title{
ADAPTABILITY EVALUATION OF ELECTRONIC VEHICLE IDENTIFICATION IN URBAN TRAFFIC: A CASE STUDY OF BEIJING
}

\author{
Hui Hu, Baowen Li, Xiang Chen, Ying Yan, Bin Ran
}

Original scientific paper

Electronic vehicle identification (EVI) technology is often introduced to implement congestion-based toll. This paper presented an ex ante evaluation method for EVI adaptability and discussed the feasibility of this technology in congestion charge on the basis of assessment. First, system dynamics was introduced to qualitatively analyze the effect of EVI on urban traffic systems with feedback chains. An EVI adaptability evaluation model was then developed based on principal component analysis (PCA) and data envelopment analysis (DEA). Given numerous output variables, a PCA model was built to reduce variable dimensionalities. Subsequently, two scenarios of EVI application under a congestion-based toll in Beijing were presented and calculated according to field data. Scenario 1 covered $5 \%$ of the total vehicles, as well as the toll zone within the 2nd Ring Road. Meanwhile, scenario 2 covered $5 \%$ more vehicles and included Zhongguancun West District based on scenario 1 . According to evaluation result, the adaptability classifications of scenarios 1 and 2 were identified as basic adaptive \& adaptive respectively, and that scenario 2 was more adaptive and feasible than scenario 1 . In addition, the adaptability trends of the two scenarios between 2003 and 2012 were analyzed and proved to be consistent with the practical situation. The findings had significant implications for policy makers who determined the priority domains of internet of things technology applications by assessing the adaptability of these technologies before deployment.

Keywords: adaptability; congestion charge; data envelopment analysis (DEA); electronic vehicle identification (EVI); evaluation

Procjena prilagodljivosti elektroničke identifikacije vozila u gradskom prometu: analiza slučaja Pekinga

Izvorni znanstveni članak

Tehnologija elektroničke identifikacije vozila (EVI) često se uvodi kako bi se izvršila naplata cestarine u vrijeme zagušenja prometa. U radu je predstavljena metoda za procjenu prilagodljivosti EVI-a te razmatrana provedivost te tehnologije u nadzoru zagušenja na temelju procjene. Najprije je određena dinamika sustava u svrhu kvalitetne analize učinka EVI-a na sustav gradskog prometa s nizom povratnih informacija. Zatim je izgrađen model za procjenu prilagodljivosti EVI-a temeljen na analizi glavnih komponenti (principal component analysis - PCA) i analizi dobivenih podataka (data envelopment analysis - DEA). Zbog brojnih izlaznih varijabli sastavljen je PCA model kako bi se smanjile veličine varijabli. Nakon toga, predstavljena su dva scenarija primjene EVI-a za naplatu cestarine u vrijeme zagušenja prometa u Pekingu. Scenario 1 je obuhvatio $5 \%$ ukupnog broja vozila, kao i naplatnu zonu unutar 2nd Ring Road. U međuvremenu, scenarijem 2 je obuhvaćeno 5 \% više vozila i uključen je Zhongguancun West District baziran na scenariju 1. Prema dobivenim rezultatima procjene, scenarij 1 je označen kao u osnovi prilagodljiv, a scenarij 2 kao prilagodljiv, odnosno scenarij 2 je prepoznat kao prilagodljiviji i izvodljiviji nego scenarij 1. Osim toga, analizirali su se trendovi prilagodljivosti dvaju scenarija u periodu između 2003 . 1 2012. te se pokazalo da su bili u skladu s postojećom situacijom. Procjenjivanjem prilagodljivosti tih tehnologija prije njihove primjene u praksi, ti su rezultati značajno utjecali na određivanje područja od prioriteta u primjeni tehnologije interneta stvari (Internet of Things-IoT).

Ključne riječi: analiza dobivenih podataka (DEA); elektronička identifikacija vozila (EVI); prilagodljivost; procjena; zagušenje prometa

\section{Introduction}

China has recently faced increasing challenges related to the energy crisis, traffic jams, and traffic pollution. According to the Beijing Transport Annual Report (2013), the number of total vehicles increased by $5 \%$ and the number of daily trips was 660000 times in 2013. The average daily traffic congestion time during workdays is 1 hour and 55 minutes [1]. Congestion charge is an effective measure to reverse this trend in Beijing and especially to relieve traffic congestion in central districts.

Electronic vehicle identification (EVI) is currently often used in congestion charge. This system uniquely identifies vehicles electronically and typically comprises a secure in-vehicle data storage element, suitable and secure interfaces, and a vehicle-to-infrastructure data communication element. Through vehicle data inquiry, identification and updating, we can manage vehicles and feed back real-time traffic situations. EVI is mainly used in vehicle management, traffic monitoring, and driver services at present. Nonetheless, this system can be applied for a city to facilitate efficient and secure electronic road toll collection, convenient vehicle inspection and testing, and vehicle registration and titling.

\section{Related work}

The United States and Europe lead in EVI application to traffic areas. In fact, the world's first open highway electronic toll collection (ETC) system opened in Oklahoma in 1991. Radio-frequency identification (RFID) application also generated interest in Europe during the 1990s. Both microwave and inductive technologies have been used in various applications, such as toll collection

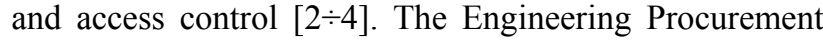
Construction (EPC) global standard in the United States currently leads in international RFID market applications. In this country, various states have implemented the ETC system E-Z Pass. Other countries that have applied ETC systems include Canada, Poland, the Philippines, Japan, and Singapore. The electronic road pricing (ERP) system in Singapore is known for being an effective and flexible congestion charging method [5]. In China, Chongqing initiated an EVI demonstration project in 2009. Furthermore, RFID tags were released to qualified vehicles to control access to the Shanghai World Expo in 2010. In Nanjing, RFID is used to protect the environment; when a vehicle travels on a main city road, a roadside station obtains real-time emission information on the vehicle [6]. Beijing began to adopt ETC systems in 2010; this city utilized EVI to unclog the traffic jams on highways and bridges and in tunnels. At present, Beijing 
is attempting to introduce EVI into the congestion charging of the central business district.

For a theoretical study, Karim Ismail et al. described a discrete event microsimulation model to investigate the implementation of automated vehicle identification (AVI) technologies at the Nordel Inspection Station in British Columbia [7]. Eun-Kyu Lee et al. experimentally evaluated the characteristics of on-vehicle RFID readers and tags to identify the critical factors that influence onvehicle RFID reading performance [8]. Jian John Lu et al. analyzed the performance of three types of AVI technologies used in toll collection, including optical/laser scanners, radio frequency, and inductive loops [9]. Mei Lam Tam et al. used AVI data to estimate the journey time of a real-time traveler information system in Hong Kong [10]. Hribernik, Karl A. et al. studied RFID application in a logistics system based on EPC global architecture and the framework of the Monetary Authority of Singapore. These researchers also defined standard processes for entities [11]. H Marais et al. investigated the suitability of ultra-high frequency passive RFID for use in EVI scenarios. A simulation scheme that models each of the key elements within an EVI environment was developed as well [12]. Phil Blythe et al. provided insight into the use of in-vehicle tags and transponders to facilitate roadside-to-vehicle data communications for electronic tolling and road-use pricing systems [13]. Minghe $\mathrm{Yu}$ et al. designed an active RFID tag-based system for the automatic identification of running vehicles on roads. The design principles and architecture of the system were presented as well [14]. Scholars have also studied related topics, such as RFID application in vehicle position identification [15], RFID security and privacy issues [16], and RFID reader scheduling [17]. With respect to technology evaluation, Ailing Huang studied the effect mechanism of intelligent transportation management systems (ITMS) on road traffic systems on the basis of fundamental diagram and entropy theories [18]. Haynes and $\mathrm{Li}$ used the probabilistic multidimensional scaling algorithm to evaluate questionnaires and to deploy intelligent transportation system (ITS) subsystems [19]. Khali Persad et al. investigated the costs, benefits, and implementation requirements of EVI in Texas via cost benefit analysis [20]. The ERTICO EVI Project consortium determined the feasibility of introducing European Union-wide EVI systems. Four functional levels were considered, namely, technological, security, economic, social, and political issues [21]. To date, evaluation contents concentrate on cost-benefit analysis, as well as safety and environment evaluation. However, these evaluations are primarily conducted after application. Hence, we must establish an ex ante evaluation method to measure the adaptability of the method in determining priority fields of Internet of Things (IoT) technologies and to support decision makers.

\section{Definition of loT adaptability in urban traffic}

Adaptability is the relationship between things and the external environment. In complex adaptive system (CAS) theory, system members are adaptive entities. Adaptability refers to entities that can interact with the environment, which is also the eternal system development process. During this process, entities develop with the environment and adjust continuously to facilitate sustainable system development.

IoT technology should adapt to urban road traffic system development. Thus, the technology not only needs to reach a certain application performance standard but also must adapt to the structure, management, and infrastructure of road traffic systems. IoT technology adaptability is defined in this study as the capability to meet the needs of urban road traffic systems for consistency and coordination with present road traffic management level. The performance of IoT technology application comprises internal factors that affect technology adaptation. By contrast, the economic, environmental, and policy aspects of urban road traffic system are external factors. In line with this information, we divide factors into two categories: IoT technology application performance and urban road traffic system characteristics. The factors in IoT technology application performance reflect the maturity and function of the technology. Meanwhile, urban road traffic system characteristics indicate the detailed features of urban traffic system development. The influence factors of IoT technology adaptability are shown in Fig. 1.

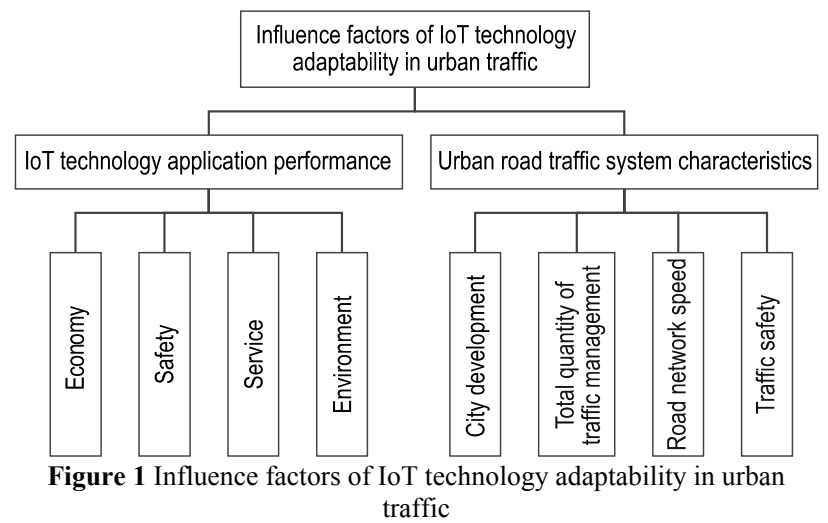

\section{Analysis of the traffic application of EVI technology 4.1 EVI technology application in urban traffic}

A single evaluation indicator system cannot comprehensively evaluate a full system that is composed of many subsystems. Moreover, the evaluation results do not have actual decision-making reference value. Thus, we select EVI technology as an evaluation objective. This objective serves as a valuable reference for IoT system evaluation. EVI is mainly used in the following three areas currently: vehicle management, traffic monitoring, and driver services [22].

Vehicle management includes annual vehicle inspection, vehicle check, and electronic road toll. Annual vehicle inspection is required in most countries to protect public safety. Vehicle information (e.g., license plate number, type, due date for inspection, driving record, and driver's license) collected, inspection result inquiry, and annual fee charges are all listed on the Internet for annual inspection. When vehicles are checked by police officers on the road, an electronic police is integrated with EVI to help these officers identify unlicensed vehicles, as well as escaping vehicles that cause accidents. 
Traffic monitoring includes dynamic traffic information collection and guidance [23]. In China, traffic flow information is collected by inductive loops and cameras, and vehicle information is mainly recorded manually. With EVI, vehicle information and real-time road situations can be collected efficiently and dynamically. EVI can also perform dynamic traffic guidance by providing drivers with suitable route information and by establishing a traffic model to aid transportation authorities in making decisions for improving transportation infrastructure.
Driver services mainly refer to safe driving management. First, EVI can be integrated with drunk driving detection and electronic identification technology to achieve dynamic driver control for drunk driving and unlicensed driving issues. Second, EVI can submit realtime speed data to a traffic management department given legal enforcement, such as speed limits. If a vehicle exceeds the speed limit, then a ticket is issued to the vehicle. The hardware architecture is depicted in Fig. 2.

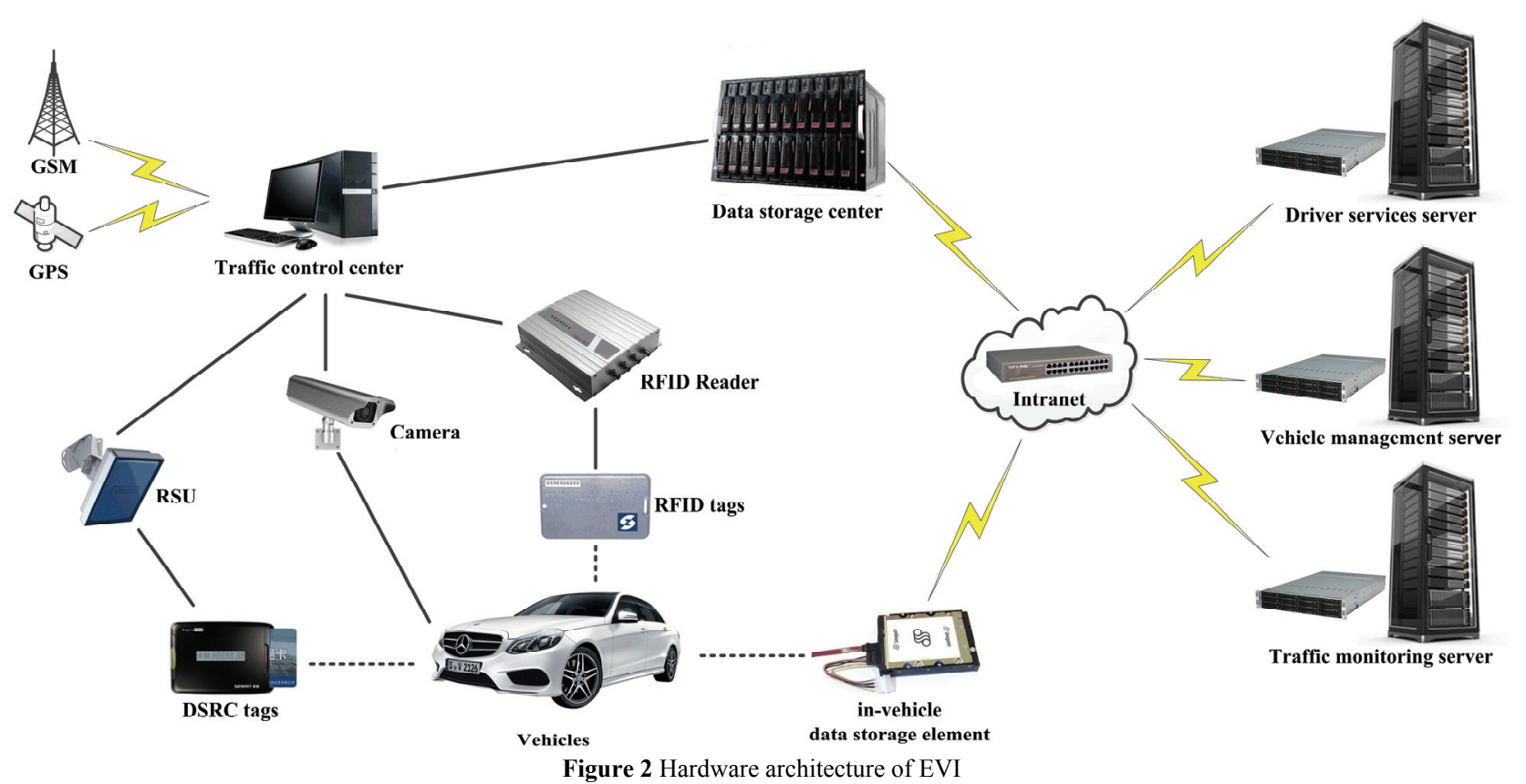

\subsection{Effect mechanism of EVI on urban traffic elements}

As the number of vehicles increases, road traffic flow increases and traveling speed decreases. In the process, the occurrence of traffic accidents is augmented and the disequilibrium of road network loads is enhanced, thereby aggravating the decline in traveling speed. Similar to Ref.[18], we analyse the interactions of these frameworks according to system dynamics theory. Moreover, EVI is introduced into this correlation framework to determine the influence of this technology. This system is a negative feedback factor in all three positive feedback chains, as indicated in Figure 3.

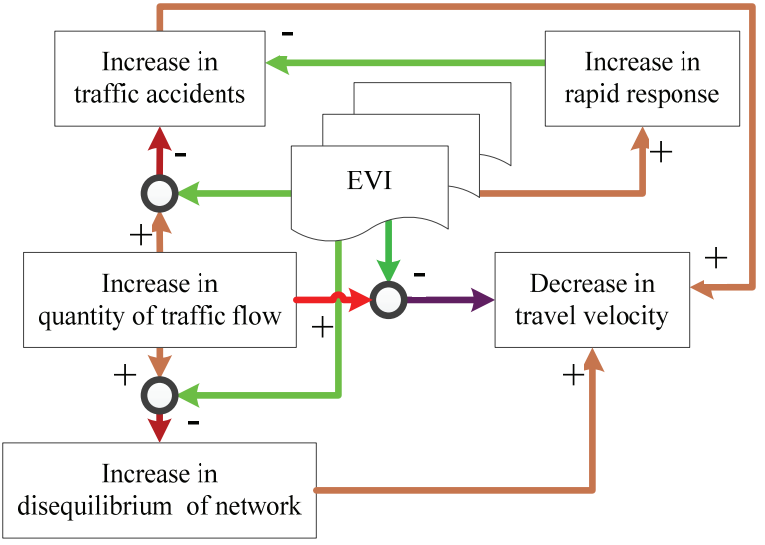

Figure 3 Correlation framework of the EVI feedback factor

\section{Evaluation model of EVI technology}

The adaptability evaluation model is divided into two parts: principal component analysis (PCA; to obtain firstlevel indicators) and the data envelopment analysis (DEA) model (to calculate adaptability value).

\subsection{Principal component analysis to obtain First-Level Indicators}

PCA is a mathematical algorithm that reduces data dimensionality while retaining most data set variations [24]. The algorithm accomplishes this reduction by identifying directions (called principal components) along which data variation is maximized. Each sample can be represented by a few numbers instead of by values for thousands of variables when a few components are considered. In this study, the following PCA models are built as shown in Eq. (1).

$$
\left\{\begin{array}{l}
Y_{1}=b_{11} y_{1}+b_{12} y_{2}+b_{13} y_{3}+b_{14} y_{4}+e_{21} \\
Y_{2}=b_{21} y_{5}+b_{22} y_{6}+b_{23} y_{7}+b_{24} y_{8}+b_{25} y_{9}+b_{26} y_{10}+e_{22} \\
Y_{3}=b_{31} y_{11}+b_{32} y_{12}+b_{33} y_{13}+e_{23} \\
Y_{4}=b_{41} y_{14}+b_{42} y_{15}+e_{24}
\end{array}\right.
$$

where $Y$ represents the vector of the principal components; $y$ is the index content vector of $Y ; b_{i j}$ represents the load coefficient; and $e_{i j}$ represents the 
residuals. The detailed calculation procedures are as follows:

(1) Sample standardization.

Given a data matrix with $\mathrm{p}$ variables and $\mathrm{n}$ samples, the initial matrix of the influence factor index system is $Y$ $=\left(y_{\mathrm{ij}}\right)_{n \times p}$. The standardized value is calculated as:

$z_{i j}=\frac{y_{i j}-\bar{y}_{j}}{s_{j}}, i=1,2, \ldots, n, j=1,2, \ldots, p$,

where $\bar{y}_{j}=\frac{\sum_{i=1}^{n} y_{i j}}{n}, s_{j}=\sqrt{\frac{\sum_{i=1}^{n}\left(y_{i j}-\bar{y}_{j}\right)^{2}}{n-1} \text {. }}$

(2) Calculation of the correlation matrix of the standardized matrix.

Assuming that $Z=\left\{z_{i j}\right\}_{m \times n}$ is a standardized sample data matrix, the correlation matrix $\boldsymbol{R}$ of this matrix is expressed as:

$\boldsymbol{R}=\left[\begin{array}{cccc}r_{11} & r_{12} & \cdots & r_{1 p} \\ r_{21} & r_{22} & \cdots & r_{2 p} \\ \vdots & \vdots & \vdots & \vdots \\ r_{p 1} & r_{p 2} & \cdots & r_{p p}\end{array}\right],(i, j=1,2, \ldots, p)$,

where the correlation is $r_{i j}=\frac{1}{n-1} \sum_{k=1}^{n} z_{i k} z_{j k}$.

The eigenvalue of $R$ can be obtained through the following equation:

$\left[\begin{array}{cccc}r_{11}-\lambda & r_{12} & \cdots & r_{1 p} \\ r_{21} & r_{22}-\lambda & \cdots & r_{2 p} \\ \vdots & \vdots & \vdots & \vdots \\ r_{p 1} & r_{p 2} & \cdots & r_{p p}-\lambda\end{array}\right]=0$

where $\lambda$ is the eigenvalue of $\boldsymbol{R}$. The eigenvector matrix of $\boldsymbol{L}$ is calculated as follows:

$\boldsymbol{L}=\left[\begin{array}{cccc}l_{11} & l_{12} & \cdots & l_{1 p} \\ l_{21} & l_{22} & \cdots & l_{2 p} \\ \vdots & \vdots & \vdots & \vdots \\ l_{p 1} & l_{p 2} & \cdots & l_{p p}\end{array}\right]$.

(3) Determination of the number of principal components extracted based on cumulative information contribution percentage.

When the cumulative percentage is $\sum_{i=1}^{m} \lambda_{i} / \sum_{i=1}^{p} \lambda_{i} \geq 0,85$, the $m$ value is determined and is sufficient to include adequate principal components.

(4) Calculation of the principal component load matrix $\boldsymbol{B}$.

The load value of the $i^{\text {th }}$ variable on the $j^{\text {th }}$ principal component is $b_{i j}=l_{i j} \sqrt{\lambda_{j}}$. The principal components load matrix is then:

$$
\boldsymbol{B}=\left(b_{i j}\right)=\left[\begin{array}{cccc}
l_{11} \sqrt{\lambda_{1}} & l_{12} \sqrt{\lambda_{2}} & \cdots & l_{1 m} \sqrt{\lambda_{m}} \\
l_{21} \sqrt{\lambda_{1}} & l_{22} \sqrt{\lambda_{2}} & \cdots & l_{2 m} \sqrt{\lambda_{m}} \\
\vdots & \vdots & \vdots & \vdots \\
l_{p 1} \sqrt{\lambda_{1}} & l_{p 2} \sqrt{\lambda_{2}} & \cdots & l_{p m} \sqrt{\lambda_{m}}
\end{array}\right] .
$$

(5) Transfer of the principal components.

According to Eq. (7), standardized index variables are transferred to the principal components:

$$
U_{i j}=z_{i}^{T} b_{j}, j=1,2, \ldots, m
$$

\subsection{Data envelopment analysis adaptability evaluation model}

The DEA $\mathrm{C}^{2} \mathrm{GS}^{2}$ model is employed in the study, as shown in Eq. (8) and (9) [25]. The input is EVI application investment, whereas the output includes data on urban road traffic system characteristics, as presented in Tab. 1. The degree of EVI to satisfy urban traffic needs is represented by $C_{h}$.

$$
\begin{aligned}
& C^{2} G S^{2}\left\{\begin{array}{l}
\operatorname{Min}\left[\theta-\varepsilon\left(\hat{e}^{\mathrm{T}} s^{-}+e^{\mathrm{T}} s^{+}\right)\right]=V_{D} \\
\text { s.t. } \sum_{j=1}^{n} \mu_{j} x_{j}+s^{-}=\theta x_{0} \\
\sum_{j=1}^{n} \mu_{j} y_{j}-s^{+}=y_{0} \\
\sum_{j=1}^{n} \mu_{j}=1 \\
\mu_{j} \geq 0, j=1,2, \ldots, n \\
s^{-} \geq 0, s^{+} \geq 0
\end{array}\right. \\
& C_{h}=\frac{\sum_{i}^{m} \theta_{i}}{m}
\end{aligned}
$$

where $m$ represents the number of decision making units (DMUs); $\theta$ is a binary variable which describes the DEA efficiency; $e^{\mathrm{T}}$ is the $\mathrm{s}$ dimension vector of $1 ; \hat{e}^{\mathrm{T}}$ is the $\mathrm{n}$ dimension vector of $1 ; \varepsilon$ is the Archimedes infinitesimal; $V_{D}$ is the optimal linear programming value; $C_{h}$ is the adaptability value; $\theta_{i}$ is the adaptability value of unit $i ; \mu_{j}$ is the weight of the input and the output; $s^{-}, s^{+}$are the slack variables; $x_{j}$ is the input vector of DMU $j ; y_{j}$ is the output vector of DMU $j ; n$ is the input number of DMU; and $s$ is the output number of DMU.

According to the definition of the $C^{2} G S^{2}$ model, the efficiency of a DMU has three stages: DEA effectiveness, weak effectiveness, and ineffectiveness. These stages cannot fully reflect the degree of EVI adaptation. Hence, the adaptability classification is divided into four levels. When $C_{h} \in(0,90 ; 1,00]$, the classification is adaptive. When $C_{h} \in(0,80 ; 0,90]$, the classification is basic adaptive. When $C_{h} \in(0,65 ; 0,80]$, the classification is lacks adaptability. When $C_{h} \in(0 ; 0,65]$, the classification is not adaptive. 
Table 1 Mathematical definition of the evaluation indicator system

\begin{tabular}{|c|c|c|}
\hline & First-level indicators & Second-level indicators \\
\hline \multirow{8}{*}{$\begin{array}{c}\text { EVI application } \\
\text { investment } \\
X \\
\text { (Input indicator) }\end{array}$} & \multirow{3}{*}{ Fixed cost $X_{1}(\mathrm{RMB})$} & Production initial cost $x_{1}(\mathrm{RMB})$ \\
\hline & & Infrastructure initial cost $x_{2}(\mathrm{RMB})$ \\
\hline & & Information center construction $\operatorname{cost} x_{3}(\mathrm{RMB})$ \\
\hline & \multirow{4}{*}{ Variable cost $X_{2}$ (RMB) } & Annual maintenance cost $x_{4}(\mathrm{RMB})$ \\
\hline & & Annual transaction costs $x_{5}(\mathrm{RMB})$ \\
\hline & & Annual newly tag cost $x_{6}(\mathrm{RMB})$ \\
\hline & & Labor cost $x_{7}(\mathrm{RMB})$ \\
\hline & Other costs $X_{3}(\mathrm{RMB})$ & Privacy release cost $x_{8}(\mathrm{RMB})$ \\
\hline \multirow{15}{*}{$\begin{array}{l}\text { Urban road traffic } \\
\text { system } \\
\text { characteristics } \\
Y \\
\text { (Output indicator) }\end{array}$} & \multirow{4}{*}{ City development $Y_{1}$} & Population $y_{1}\left(10^{4}\right.$ persons $)$ \\
\hline & & GDP $y_{2}\left(10^{8} \mathrm{RMB}\right)$ \\
\hline & & Income per person $y_{3}(\mathrm{RMB})$ \\
\hline & & Ratio of urban road traffic infrastructure investment $y_{4}(\%)$ \\
\hline & \multirow{6}{*}{$\begin{array}{l}\text { Traffic management total } \\
\text { quantity } Y_{2}\end{array}$} & Vehicle volume $y_{5}\left(10^{4}\right.$ units $)$ \\
\hline & & Total length of urban roads $y_{6}(\mathrm{~km})$ \\
\hline & & Social public parking spaces $y_{7}\left(10^{4}\right.$ spaces $)$ \\
\hline & & Total quantity of daily travel $y_{8}\left(10^{4}\right.$ person-times $)$ \\
\hline & & Proportion of bus trips $y_{9}(\%)$ \\
\hline & & Proportion of private car trips $y_{10}(\%)$ \\
\hline & \multirow{3}{*}{ Road network speed $Y_{3}$} & Average speed of urban expressway $y_{11}(\mathrm{~km} / \mathrm{h})$ \\
\hline & & Average speed of arterial road $y_{12}(\mathrm{~km} / \mathrm{h})$ \\
\hline & & Average speed of road network $y_{13}(\mathrm{~km} / \mathrm{h})$ \\
\hline & \multirow{2}{*}{ Traffic safety $Y_{4}$} & Mortality rate of ten thousand cars $y_{14}(\%)$ \\
\hline & & Accident rate of ten thousand cars $y_{15}(\%)$ \\
\hline
\end{tabular}

\section{Case study}

\subsection{Data collection}

Congestion charge is a necessary and effective measure to relieve traffic congestion in Beijing, especially in the urban central district. The congestion charge policy implemented in London is effective, and $65 \%$ of commuters in Singapore use public transport with the aid of a congestion charge system. Consequently, air pollution is significantly reduced [26]. At present, the Beijing Public Security and Traffic Management Bureau is attempting to investigate and analyze EVI application in certain central congested areas. Hence, Beijing is chosen as the study case for the current research.

DEA is a method used to analyze the relative effectiveness of DMU of same type. Therefore, the selected DMUs should have the same point of aim, external environment, and input/output indicators. Moreover, all input/output indicator data should have been obtained in the same period. Our ex ante evaluation method collects related urban traffic data from Beijing in the period of 2003-2012 for input into the DEA model, as shown in Tab. 2.

Table 2 Basic data on urban road traffic characteristics in Beijing (2003-2012)

\begin{tabular}{|c|c|c|c|c|c|c|c|c|c|c|}
\hline Factor $\quad$ Year & 2003 & 2004 & 2005 & 2006 & 2007 & 2008 & 2009 & 2010 & 2011 & 2012 \\
\hline$y_{1}\left(10^{4}\right.$ persons $)$ & 1456 & 1493 & 1538 & 1581 & 1633 & 1695 & 1755 & 1961 & 2019 & 2069 \\
\hline$y_{2}\left(10^{8} \mathrm{RMB}\right)$ & 5007,2 & 6033,2 & 6969,5 & 8117,8 & 9846,8 & 11115 & 12153 & 14113,6 & 16251,9 & 17879,4 \\
\hline$y_{3}(\mathrm{RMB})$ & 13883 & 15638 & 17653 & 19305,5 & 21989 & 24725 & 26746 & 29073 & 32903 & 36469 \\
\hline$y_{4}(\%)$ & 0,1112 & 0,0064 & 0,0058 & 0,0103 & 0,0194 & 0,0152 & 0,011 & 0,0068 & 0,006 & 0,004 \\
\hline$y_{5}\left(10^{4}\right.$ units $)$ & 212,4 & 229,6 & 258,3 & 287,6 & 312,8 & 350,4 & 401,9 & 480,9 & 498,4 & 520,0 \\
\hline$y_{6}(\mathrm{~km})$ & 3905 & 3898 & 4073 & 4419 & 4460 & 6186 & 6347 & 6355 & 6285 & 6271 \\
\hline$y_{7}\left(10^{4}\right.$ spaces $)$ & 55,7 & 67,8 & 79,8 & 94,5 & 107,4 & 111,1 & 127,7 & 139,4 & 147,1 & 161,0 \\
\hline $\begin{array}{c}y_{8}\left(10^{4} \text { person- }\right. \\
\text { times })\end{array}$ & 1988 & 2000 & 2105 & 2180 & 2275 & 2637 & 2746 & 2904 & 2873 & 3033 \\
\hline$y_{9}(\%)$ & 26,4 & 24,7 & 24,1 & 24,4 & 27,5 & 28,8 & 28,9 & 28,2 & 28,2 & 27,2 \\
\hline$y_{10}(\%)$ & 26,9 & 28,5 & 29,8 & 31,6 & 32,6 & 33,6 & 34 & 34,2 & 33 & 32,6 \\
\hline$y_{11}(\mathrm{~km} / \mathrm{h})$ & 57,9 & 54,2 & 50,5 & 40,2 & 32,8 & 35,6 & 36,2 & 35,1 & 35,5 & 35,3 \\
\hline$y_{12}(\mathrm{~km} / \mathrm{h})$ & 28,3 & 27,9 & 26,9 & 26,7 & 20,5 & 23,1 & 23,1 & 22,2 & 21,9 & 21,8 \\
\hline$y_{13}(\mathrm{~km} / \mathrm{h})$ & 36,8 & 36,2 & 34,9 & 33,3 & 25,6 & 27,6 & 28,9 & 23,9 & 26,4 & 26,0 \\
\hline$y_{14}(\%)$ & 51,05 & 37,18 & 24,63 & 20,2 & 17,05 & 11,25 & 9,49 & 8,65 & 8,33 & 6,15 \\
\hline$y_{15}(\%)$ & 7,73 & 7,1 & 5,87 & 4,78 & 3,78 & 2,81 & 2,44 & 2,03 & 1,85 & 1,77 \\
\hline
\end{tabular}

In China, EVI application remains at the initial stage. Only few cities have initiated EVI pilot application. Thus, the statistical data from the United States and European ERTICO are introduced as references for DEA model calculation in this study. Moreover, EVI application and popularization necessitate complex system engineering and should be implemented step by step. In fact, EVI can usually be implemented gradually according to vehicle type, areas, and corridors. In this Beijing case study, the $2^{\text {nd }}$ Ring Road and $5 \%$ of private vehicles are selected in the first step of applying EVI to the region (scenario 1), as shown in Fig. 4a. The red circle in the figure represents 
the $2^{\text {nd }}$ Ring Road of Beijing while the dark spots represent the positions of overhead readers.

Scenario 2 is based on scenario 1; however, Zhongguancun West District (ZWD) is also added to the toll zone and $10 \%$ of vehicles are equipped with RFID

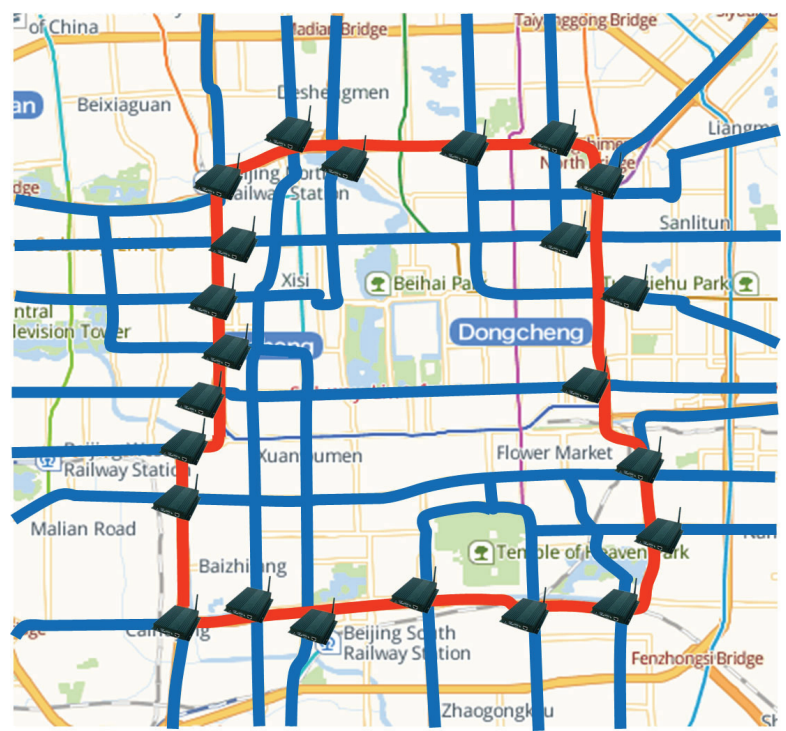

(a) Scenario 1

Figure 4 Toll zones in the scenarios
EVI application costs include the following: initial production cost, initial infrastructure cost, annual maintenance cost, annual transaction cost, and annual new tag and labor costs. The cost unit of the following formulas is $10,000 \mathrm{RMB}$.

(1) The initial production cost is written as $x_{1}=N_{V} \cdot P_{p}$, where $N_{V}$ is the number of vehicles registered and $P_{p}$ is the production price per tag.

(2) The initial infrastructure cost is expressed as $x_{2}=$ $N_{h} \cdot P_{h}+L_{r} \cdot N_{p k} \cdot P_{r}$, where $N_{h}$ is the number of handheld readers required; $L_{r}$ is the road length; $N_{p k}$ is the number of readers required every one kilometer, $P_{h}$ is the price per handheld reader; and $P_{r}$ is the price per overhead reader. tags. ZWD is located at the central Haidian District and is the core of Zhongguancun Technology Park. ZWD is surrounded by Zhongguancun Street, North $4^{\text {th }}$ Ring Road, Suzhou Street, and Haidian South Road, as indicated in Fig. $4 \mathrm{~b}$.

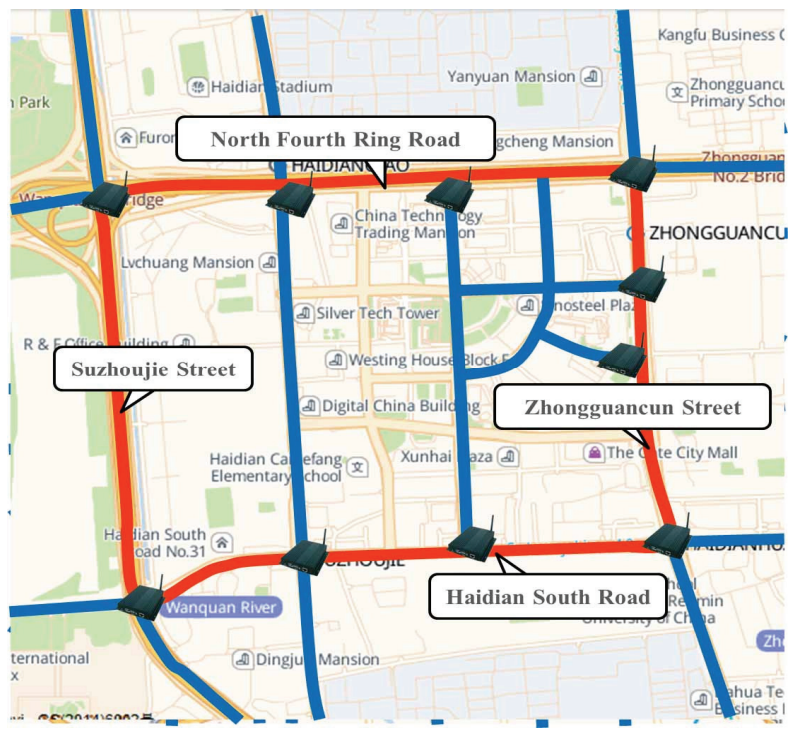

(b) Scenario 2
(3) The annual maintenance cost is written as $x_{4}=\left(N_{h}\right.$ $\left.+L_{r} \cdot N_{p k}\right) \cdot M$, where $M$ is the annual maintenance cost per reader.

(4) The annual transaction cost is expressed as $x_{5}=$ $\left(N_{h}+L_{r} \cdot N_{p k}\right) \cdot N_{t} \cdot P_{t}$, where $N_{t}$ is the annual number of transactions per reader and $P_{t}$ is the price per transaction.

(5) The annual new tag cost is written as $x_{6}=x_{1} \cdot P$, where $P$ is the annual tag replacement percentage.

(6) The labor cost is expressed as $x_{7}=N_{h} \cdot P_{m}$, where $P_{m}$ is the annual staff income.

Tab. 3 shows the reference values used to calculate costs, and the detailed units of all variables are shown in it

\begin{tabular}{|c|c|c|c|c|c|c|c|}
\hline \multirow{2}{*}{ Variable } & \multirow{2}{*}{ Description } & \multicolumn{2}{|c|}{ Value } & \multirow{2}{*}{ Variable } & \multirow{2}{*}{ Description } & \multicolumn{2}{|c|}{ Value } \\
\hline & & Scenario 1 & Scenario 2 & & & Scenario1 & Scenario 2 \\
\hline$N_{V}$ & $\begin{array}{l}\text { Number of vehicles } \\
\text { registered } \\
\text { (unit) }\end{array}$ & 213550 & 427100 & $P_{r}$ & $\begin{array}{c}\text { Price per } \\
\text { overhead reader } \\
(\mathrm{RMB})\end{array}$ & 18000 & 18000 \\
\hline$P_{m}$ & $\begin{array}{l}\text { Staff annual income } \\
\text { (RMB) }\end{array}$ & 50000 & 50000 & $P_{h}$ & $\begin{array}{c}\text { Price per } \\
\text { handheld reader } \\
(\mathrm{RMB})\end{array}$ & 20000 & 20000 \\
\hline$P_{p}$ & $\begin{array}{l}\text { Price of production } \\
\text { per tag (RMB) }\end{array}$ & 25 & 25 & $M$ & $\begin{array}{l}\text { Annual } \\
\text { maintenance cost } \\
\text { per reader }(\mathrm{RMB})\end{array}$ & 1200 & 1200 \\
\hline$N_{h}$ & $\begin{array}{c}\text { Number of } \\
\text { handheld readers } \\
\text { (set) }\end{array}$ & 8 & 13 & $N_{t}$ & $\begin{array}{l}\text { Annual number } \\
\text { of transactions } \\
\text { per reader } \\
\text { (times) }\end{array}$ & 20000 & 20000 \\
\hline$L_{r}$ & Road length ( km) & 32,7 & 50,0 & $P_{t}$ & $\begin{array}{c}\text { Price per } \\
\text { transaction } \\
(\mathrm{RMB})\end{array}$ & 0,08 & 0,08 \\
\hline$N_{p k}$ & $\begin{array}{c}\text { Number of reader } \\
\text { needed } \\
\text { every one kilometer } \\
\text { (set) }\end{array}$ & 0,6 & 0,6 & $P$ & $\begin{array}{l}\text { Annual } \\
\text { percentage of tag } \\
\text { replacement } \\
(\%)\end{array}$ & 10 & 10 \\
\hline
\end{tabular}




\begin{tabular}{|c|c|c|c|c|c|}
\hline \multirow{2}{*}{ Cost } & \multirow{2}{*}{ Description } & \multicolumn{2}{|c|}{ Value $(10,000 \mathrm{RMB})$} & \multicolumn{2}{|c|}{ Percent $(\%)$} \\
\hline & & Scenario 1 & Scenario 2 & Scenario 1 & Scenario 2 \\
\hline$x_{1}$ & Initial production cost & 533,875 & 1067,750 & 77,70 & 80,19 \\
\hline$x_{2}$ & Initial infrastructure cost & 52 & 80 & 7,57 & 6,01 \\
\hline$x_{3}$ & Information center construction cost & 0 & 0 & 0 & 0 \\
\hline$x_{4}$ & Annual maintenance cost & 3,36 & 5,16 & 0,49 & 0,39 \\
\hline$x_{5}$ & Annual transaction costs & 4,48 & 6,88 & 0,65 & 5,17 \\
\hline$x_{6}$ & Annual new tag cost & 53,388 & 106,78 & 7,77 & 8,02 \\
\hline$x_{7}$ & Labor cost & 40 & 65 & 5,82 & 4,88 \\
\hline$X$ & Total cost & 687,103 & 1331,57 & 100 & 100 \\
\hline
\end{tabular}

The Intelligent Transport Control and Management Platform and the Intelligent Transport Information Dissemination Center built by the Beijing Public Security and Traffic Administration Bureau are already operating in Beijing. Hence, we need not construct an EVI information center. Nonetheless, EVI technology has certain drawbacks, such as privacy issues, that generate public resistance to the use of this technology. Therefore, privacy cost should be added to the total cost in the future to enhance the scientific credibility of the adaptability evaluation.

The detailed costs of EVI application to scenarios in Beijing are calculated and presented in Tab. 4.

\subsection{Data analysis}

According to Tab. 3 , input $X$ is calculated. In scenario $1, X_{1}=585875$ and $X_{2}=101228$. In scenario $2, X_{1}=$ 1147,75 and $X_{2}=183,82$. Then, $Y$ is calculated with the PCA model given Eq. (1). The calculated results are listed in Tab. 5.
Table 5 PCA results of output $Y$

\begin{tabular}{|c|c|c|c|c|}
\hline & $Y_{1}$ & $Y_{2}$ & $Y_{3}$ & $Y_{4}$ \\
\hline 2003 & 2,8232 & $-2,6195$ & 2,5622 & 2,6464 \\
\hline 2004 & 1,1283 & $-2,4951$ & 2,1896 & 1,8022 \\
\hline 2005 & 0,8388 & $-2,0467$ & 1,6249 & 0,8296 \\
\hline 2006 & 0,6226 & $-1,3207$ & 0,7693 & 0,2789 \\
\hline 2007 & 0,3406 & $-0,3474$ & $-1,7263$ & $-0,1838$ \\
\hline 2008 & $-0,1002$ & 1,0621 & $-0,8352$ & $-0,7603$ \\
\hline 2009 & $-0,4756$ & 1,6241 & $-0,6535$ & $-0,9591$ \\
\hline 2010 & $-1,2153$ & 2,0561 & $-1,4487$ & $-1,1279$ \\
\hline 2011 & $-1,7462$ & 1,9762 & $-1,2032$ & $-1,1997$ \\
\hline 2012 & $-2,2161$ & 2,1108 & $-1,2791$ & $-1,3263$ \\
\hline
\end{tabular}

Finally, the input $X$ data of the two scenarios (also presented in Tab. 5) are added to the DEA model. The DEA calculation results with Matlab 2014 are shown in Tabs. 6 and 7.

In both scenarios, $C_{h}^{1}=0,858552$ and $C_{h}^{2}=0,905381$. Tab. 6 shows that the $\mathrm{s}$ values of the two scenarios are almost 0 . Then, we can compare the $\theta$ values of the two scenarios to analyze the effectiveness of the DEA models, as presented in Fig. 5.

Table $6 s$ values of the two scenarios

\begin{tabular}{|c|c|c|c|c|c|c|c|}
\hline & Scenario no. & $s_{1}^{-}$ & $s_{2}^{-}$ & $s_{1}^{+}$ & $s_{2}^{+}$ & $s_{3}^{+}$ & $s_{4}^{+}$ \\
\hline \multirow{2}{*}{2003} & 1 & 0,000011613625842 & 0,110992867267717 & 0,000006058673756 & 0,000006858058272 & 0,000002017311740 & 0,000000259133408 \\
\hline & 2 & 0,000321195300098 & 0,340703959414707 & 0,000000357767849 & 0,477778831031440 & 0,000452929629218 & 0,003693261507472 \\
\hline \multirow{2}{*}{2004} & 1 & 0,000091272721396 & 0,123069691295183 & 0,019290039049849 & 0,004470131730547 & 0,002182737051358 & 0,000540751214292 \\
\hline & 2 & 0,052683893611046 & 0,000000631571017 & 0,313723707868184 & 0,646753455777521 & 0,000296032244120 & 0,006533214113534 \\
\hline \multirow{2}{*}{2005} & 1 & 0,000000023820636 & 0,260826809388687 & 0,000010938620950 & 0,000010996573701 & 0,000000845429152 & 0,000038186621666 \\
\hline & 2 & 0,000019397562636 & 0,000654117589484 & 0,014992942456763 & 1,572971392583566 & 0,003657633346686 & 0,091475411560013 \\
\hline \multirow{2}{*}{2006} & 1 & 0,000009978881500 & 0,000065727788318 & 0,000784085264394 & 0,007217301705152 & 0,000160748033874 & 0,206509747927487 \\
\hline & 2 & 0,002421740003450 & 0,385315377781870 & 0,002963552404787 & 1,006365084612589 & 0,000646708573052 & 0,431169483734541 \\
\hline \multirow{2}{*}{2007} & 1 & 0,000088319847437 & 0,069902566655704 & 0,053861032957560 & 0,044433224242118 & 0,030329981396825 & 0,002266209587286 \\
\hline & 2 & 0,048318020779236 & 0,137476963300461 & 0,001377400343643 & 1,134482346392586 & 0,534992285414932 & 0,322109388761687 \\
\hline \multirow{2}{*}{2008} & 1 & 0,008039886192147 & 0,133863366379487 & 0,000705239008085 & 0,031967358405235 & 0,000226560240570 & 0,016590761069865 \\
\hline & 2 & 0,001792827418906 & 0,194148793904968 & 0,004670569148212 & 0,000706995196860 & 0,000042756692739 & 0,512101876452583 \\
\hline \multirow{2}{*}{2009} & 1 & 0,000180225309053 & 0,268585819145911 & 0,000009694855742 & 0,000569805231690 & 0,000001595403688 & 0,000247449156662 \\
\hline & 2 & 0,015746087353758 & 0,000000494302718 & 0,011080584707920 & 0,069750919331715 & 0,003792255031597 & 0,423085879733286 \\
\hline \multirow{2}{*}{2010} & 1 & 0,000337512430859 & 0,133556318029537 & 0,000483832148882 & 0,002424128067067 & 0,000667376273409 & 0,022731578548762 \\
\hline & 2 & 0,000821632553995 & 0,382524063861256 & 0,000001912390060 & 0,007700833385945 & 0,299869143672119 & 0,439458595546339 \\
\hline \multirow{2}{*}{2011} & 1 & 0,000271911388434 & 0,134798106830896 & 0,003438185687229 & 0,030844213415520 & 0,000032404587231 & 0,033820232630046 \\
\hline & 2 & 0,001870589680438 & 0,443410052871846 & 0,000005907971882 & 0,716211134766055 & 0,204016688469561 & 0,320022691977326 \\
\hline \multirow{2}{*}{2012} & 1 & 0,000000080833679 & 0,248602570821904 & 0,000004765850033 & 0,000050578046645 & 0,000000036382575 & 0,000000210452057 \\
\hline & 2 & 0,001719013833451 & 0,504205522850246 & 0,469578076614524 & 0,941300406400693 & 0,453592228376920 & 0,527374917450751 \\
\hline
\end{tabular}

Table $7 \theta$ values of the two scenarios

\begin{tabular}{|c|c|c|c|c|c|}
\hline Year & 2003 & 2004 & 2005 & 2006 & 2007 \\
\hline Scenario 1 & 0,777753291541012 & 0,834654720823746 & 0,849054764746688 & 0,846289720322238 & 0,856602304420662 \\
\hline Scenario 2 & 0,815846908664817 & 0,86177847551124 & 0,884873046875000 & 0,902395885813551 & 0,915087426470635 \\
\hline Year & 2008 & 2009 & 2010 & & 2011 \\
\hline Scenario 1 & 0,843692934527644 & 0,876419505652739 & 0,882898774158675 & 0,893031394027639 & 0,925124363456853 \\
\hline Scenario 2 & 0,877165187249909 & 0,913427708754316 & 0,935089856519513 & 0,964325702151968 & 0,972421054089391 \\
\hline
\end{tabular}

The adaptability classification of scenarios 1 and 2 in Beijing should be basic adaptive and adaptive, respectively, according to the classification standard. Fig.
5 indicates that the average $\theta$ value of scenario 2 is higher than that of scenario 1.Thus, the DEA of scenario 2 is more effective than that of scenario 1. In addition, 
scenario 2 is better than scenario 1 in terms of technology adaptability to urban traffic in Beijing.

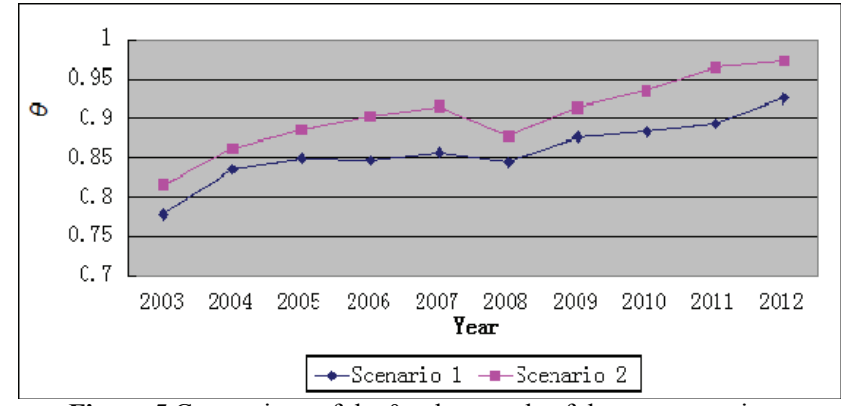

Figure 5 Comparison of the $\theta$ value trends of the two scenarios

\section{Conclusions and future work}

The study focused on the adaptability evaluation of EVI in congestion charge, especially on the selection of evaluation indicators and the improvement of the evaluation method to provide reference for EVI planning and implementation. The feedback chain approach of system dynamics was introduced to determine the interactive mechanism of EVI technology and of urban traffic systems. The adaptability of this technology application in urban traffic was then evaluated based on certain factors and on indicator analysis results. PCA and DEA models were also built to calculate adaptability value and to identify model classifications.

Two scenarios were presented in the case study, and their adaptabilities were assessed. The adaptability classifications of these scenarios were basic adaptive and adaptive. This conclusion was consistent with that from the investigation and assessment by Beijing's Traffic Management Department. Fig. 5 shows that the $\theta$ value curve trends of the two scenarios are basically increasing, thus indicating that EVI adaptability improves over time. EVI is a negative feedback factor in urban traffic elements. This system can reduce the number of traffic accidents, increase travel velocity, increase network load equilibrium, and augment response capacity. EVI implementation is increasingly necessary as the number of vehicles increases and the traffic situation worsens over time. However, the $\theta$ values in the two scenarios decreased considerably in 2008; this occurrence is attributed to the fact that in the summer of 2008, when Beijing was hosting the Olympic Games, the city took drastic measures to reduce the number of cars on the roads. The municipal authority of Beijing temporarily implemented the measure of car usage based on odd- and even-numbered license plates. Thus, the traffic situation obviously improved. Another reason for this phenomenon is the establishment of an ITMS in the same year. This ITMS is a type of ITS application in road traffic management; system deployment was initiated in 2004 in Beijing, but the ITMS was only fully established and practiced in 2008. Thus, EVI adaptability value decreased significantly. All of these analysis findings prove that the method proposed in this study is reasonable and scientific.

The cost data in this study were derived from both foreign studies and domestic investigations. In the future, we intend to track the development of EVI application and popularization in Beijing to collect more practical data, thus improving the reasonability and accuracy of the evaluation results. Moreover, this method can be used to evaluate different EVI application scenarios or other IoT technologies; these assessments serve as references for decision makers.

\section{Acknowledgement}

The study was supported by the China National Science and Technology Support Program (2014BAH23F01), Fundamental Research Funds for the Central Universities of China (2014G1221020), and the National Natural Science Foundation of China (51308059).

\section{References}

[1] Xiaoming Liu; Yongshen Quan; Jifu Guo; Xian Li et al. Beijing Transport Annual Report (2013). Beijing Transportation Research Center, Beijing, 2013.

[2] Ahmed, M. M.; Abdel-Aty, M. A. The Viability of Using Automatic Vehicle Identification Data for Real-Time Crash Prediction. // IEEE Transactions on Intelligent Transportation Systems. 13, 2(2012), pp. 459-468. DOI: 10.1109/TITS.2011.2171052

[3] Sangeeta Pandey; Yamuna Rai; Shipra Mishra. Fully Automated Toll Tax Collection Using RF Technology. // VSRD-International Journal of Electrical, Electronics \& Communication Engineering. 2, 6(2012), pp. 417-420.

[4] Pickford, A. Requirements for a National EVI System. // The Institution of Engineering and Technology Seminar on RFID and Electronic Vehicle Identification in Road Transport / Herts, 2006, pp. 66-78.

[5] Ministry of Transport, Singapore. How can we control congestion? 2014. URL: http://www.mot.gov.sg/TransportMatters/Public-Transport/How-can-we-control-congestion/. (03.12.2015)

[6] Wenjing Zhao. Study on Electronic Vehicle Identification System Based on RFID. Master Thesis of JiangSu University, Zhenjiang, China, 2008.

[7] Ismail, K.; Lim, C.; Sayed, T. Simulation and Evaluation of Automated Vehicle Identification at Weigh-in-Motion Inspection Stations: Case Study from British Columbia, Canada. // Transportation Research Board 89 ${ }^{\text {th }}$ Annual Meeting / Washington, D. C., 2010, pp. 140-150.

[8] Eun-Kyu Lee; Young Min Yoo; Chan Gook Park; Minsoo Kim; Mario Gerla. Installation and Evaluation of RFID Readers on Moving Vehicles. // the $6^{\text {th }}$ ACM International Workshop on Vehicular Internet Working / Beijing, 2009, pp. 99-108.

[9] Jian John Lu; Michael J. Rechtorik; Shiyu Yang. Automatic Vehicle Identification Technology Applications to Toll Collection Services. // Transportation Research Board $76^{\text {th }}$ Annual Meeting / Washington, D. C., 1997, pp. 18-25.

[10] Mei Lam Tam; William H.K. Lam. Application of Automatic Vehicle Identification Technology for Real-time Journey Time Estimation. // Information Fusion. 12, 1(2011), pp. 11-19. DOI: 10.1016/j.inffus.2010.01.002

[11] Hribernik, K. A.; Warden, T.; Thoben, K.-D.; Herzog, O. An Internet of Things for Transport Logistics - An Approach to Connecting the Information and Material Flows in Autonomous Cooperating Logistics Processes. // the 12th International MITIP Conference on Information Technology \& Innovation Processes of the Enterprises / Denmark, 2010, pp. 54-67.

[12] Marais, H.; Grobler, M. J.; Holm, J. E. W. Modelling of an RFID-based Electronic Vehicle Identification System. // IEEE AFRICON 2013 / Mauritius, 2013, pp. 1-5. 
[13] Blythe, P. RFID for Road Tolling, Road-use Pricing and Vehicle Access Control. // IEE Colloquium on RFID Technology. 123, (1999), pp. 1-16.

[14] Minghe Yu; Dapeng Zhang; Yurong Cheng; Mingshun Wang. An RFID Electronic Tag based Automatic Vehicle Identification System for Traffic IOT Applications. // 2011 IEEE Chinese Control and Decision Conference / Mianyang, China, 2011, pp. 4192-4197. DOI: 10.1109/CCDC.2011.5968962

[15] Sangdo Park; Hongchul Lee. Self-Recognition of Vehicle Position Using UHF Passive RFID Tags. // IEEE Transactions on Industrial Electronics. 60, 1(2013), pp. 226-234. DOI: 10.1109/TIE.2012.2185018

[16] Ma, D.; Prasad, A. K. A Context-Aware Approach for Enhanced Security and Privacy in RFID Electronic Toll Collection Systems. // 2011 IEEE Consumer Communications and Networking Conference / Maui, Hawaii, 2011, pp. 1-6.

[17] Alcaraz, J. J.; Vales-Alonso, J.; Garcia-Haro, J. RFID Reader Scheduling for Reliable Identification of Moving Tags. // IEEE Transactions on Automation Science and Engineering. $\quad 10, \quad 3(2013), \quad$ pp. 816-828. DOI: 10.1109/TASE.2012.2211351

[18] Ailing Huang; Wei Guan; Yimei Chang; Zhen Yang. Analysis of ITMS System Impact Mechanism in Beijing Based on FD and Traffic Entropy. // Discrete Dynamics in Nature \& Society, 12, 12(2012), pp. 1951-1965. DOI: $10.1155 / 2012 / 350847$

[19] K. E. Haynes; M. Li. Analytical Alternatives in Intelligent Transportation System (ITS) Evaluation. // Research in Transportation Economics. 8, 1(2004), pp. 127-149. DOl: 10.1016/S0739-8859(04)08007-2

[20] Persad, K.; Walton, C. M.; Wang, Z.; Hussain, S.; Robertson, C. Electronic Vehicle Identification: Industry Standards, Performance, and Privacy Issues. Project 05217-P2, The University of Texas at Austin, Texas, USA, 2007.

[21] EVI Project consortium. Feasibility Study on Electronic Vehicle Identification. Publication SUB-B27020B-E3-EVI2002-S07.18393, European Commission DG TREN, 2004.

[22] Cheng, W.; Wang, S. L.; Cheng, X. Z. Virtual Track: Applications and Challenges of the RFID System on Roads. // IEEE Network, 28, 1(2014), pp. 42-47. DOI: 10.1109/MNET.2014.6724105

[23] Sedano, J.; Portal, M.; Hernandez Arauzo, A.; Villar, J. R. et al. Intelligent System for Electric Vehicle Charging: Design and Operation. // DYNA, 88, 6(2013), pp. 644-651.

[24] Ian Jolliffe. Principal Component Analysis (Second edition). Springer Netherlands, Berlin, 2002.

[25] Asmild, M.; Paradi, J. C.; Reese, D. N.; Tam, F. Measuring Overall Efficiency and Effectiveness Using DEA. // European Journal of Operational Research. 178, 1(2007), pp. 305-321. DOI: 10.1016/j.ejor.2006.01.014

[26] Danish Architecture Center (DAC). Singapore: the World's First Digital Congestion Charging System. 2014. URL: www.dac.dk/en/dac-cities/sustainable-cities/allcases/transport/singapore-the-worlds-first-digitalcongestion-charging-system/(07.05.2014)

\section{Authors' addresses}

Hui Hu, Ph.D., Associate Professor (Corresponding Author) School of Automobile, Chang'an University, Middle Section of South 2nd Ring Road, Xi'an, 710064, Shaanxi Province, P. R. China

E-mail: huhui@chd.edu.cn

\section{Baowen Li, Ph.D., Assistant Professor}

School of Traffic and Transportation, Beijing Jiaotong University, No. 3 Shangyuancun, Haidian District, Beijing, 100044, P. R. China

E-mail: lbw@bjtu.edu.cn

\section{Xiang Chen, Graduate student}

School of Automobile, Chang'an University, Middle Section of South 2nd Ring Road, Xi'an, 710064, Shaanxi Province, P. R.

China.

E-mail: chenxiang@chd.edu.cn

\section{Ying Yan, Ph.D., Associate Professor}

School of Automobile, Chang'an University, Middle Section of South 2nd Ring Road, Xi'an, 710064, Shaanxi Province, P. R. China.

E-mail: yanying2199@chd.edu.cn

\section{Bin Ran, Ph.D., Professor}

Department of Civil \& Environmental Engineering, University of Wisconsin-Madison, 1212 Engineering Hall, 1415 Engineering Drive, Madison, WI 53706, USA

E-mail: bran@wisc.edu 